\title{
VIRULENCE OF ESCHERICHIA COLI IN ASCENDING URINARY-TRACT INFECTION IN MICE
}

\author{
T. IWAHI, Y. ABE AND K. TSUCHIYA \\ Central Research Division, Takeda Chemical Industries Ltd, 2-17-85, Jusohonmachi, \\ Yodogawa-kuOsaka,532, Japan
}

\begin{abstract}
SUMmaRY. The virulence of Escherichia coli strains in ascending urinary-tract infection was studied in mice drinking a $5 \%$ glucose solution; factors determining the virulence were examined. Of 33 strains, 8 (group I) infected the bladder and kidney, 10 (group II) infected only the bladder, while the remaining 15 strains (group III) did not cause infection. The adherence of group-I and group-II strains to bladder epithelial cells in vitro was inhibited by D-mannose. In group III, 13 strains barely adhered to the epithelial cells, while two strains showed an adherence unaffected by D-mannose. Most strains in groups I and II agglutinated erythrocytes of guinea-pig, chicken, and horse, and cells of Candida albicans in a mannose-sensitive manner. All strains in groups I and II had fimbriae. Virulence for the urinary tract was not directly related with O-serotype, intraperitoneal virulence, ability to grow in mouse urine, ability to ferment dulcitol, production of haemolysin, susceptibility to serum bactericidal activity, or susceptibility to antibiotics. These results suggest that the adherence of the E. coli to mouse-bladder epithelial cells in a mannose-sensitive manner plays an important role in the development of urinary-tract infection in mice and that the adherence is probably mediated by type- 1 or closely related fimbriae.
\end{abstract}

\section{INTRODUCTION}

The majority of urinary-tract infections (UTI), especially of acute and uncomplicated episodes, are caused by Escherichia coli. The prevalence of E. coli in such infections is assumed to result from its proximity to the gastrointestinal tract (Montgomerie, 1978). Early epidemiological studies suggested that $E$. coli isolated from UTI were those that prevailed in the faeces at the time of infection (Turck, Petersdorf and Fournier, 1962; Vosti et al., 1964), but subsequent reports indicated that pathogenicity of $E$. coli in UTI might correlate with special properties such as the production of haemolysin (Cooke and Ewins, 1975; Minshew et al., 1978), resistance to serum bactericidal activity (Olling, 1977; Björksten and Kaijser, 1978), and the type or amount of K antigen (Glynn, Brumfitt and Howard, 1971; Kaijser, 1973; McCabe et 
al., 1975; Kaijser et al., 1977). More recently, several authors have shown that E. coli isolated from the urine of patients with UTI adhere better to epithelial cells from the urinary tract or from the periurethral area than do those isolated from patients with asymptomatic bacteriuria or from faeces of healthy persons, and have suggested that the adherence of $E$. coli to uro-epithelial cells plays an important role in the initiation of UTI (Svanborg Ede̊n et al. 1976; Schaeffer, Amundsen and Schmidt, 1979; Källenius, Möllby and Winberg, 1980; van den Bosch et al., 1980). However, the nature of the virulence factors of $E$. coli in UTI is still a matter of conjecture.

The present study was designed to determine possible differences in urinary virulence among $E$. coli strains in a quantitative way and to examine possible factors affecting the virulence. The ascending UTI model in mice drinking the $5 \%$ glucose solution of Keane and Freedman (1967) was used as the test of urinary virulence. This model avoids artificial manipulations that have usually been necessary to produce experimental UTI via the ascending route in animals (Cotran, 1969).

\section{MATERIALS AND METHODS}

Bacterial strains. A total of 33 strains of E. coli were used; 30 were isolated from extraintestinal clinical sources, and three were laboratory strains, NIHJ JC-2 and K 12 from our collection, and K12 ML1410 kindly supplied by Dr S. Mitsuhashi (Gumma University, Japan). All strains were maintained on Trypticase Soy Agar (TSA; BBL Microbiology Systems, Cockeysville, MD) slopes at $4^{\circ} \mathrm{C}$. As a rule, bacterial strains were cultured in Brain Heart Infusion Broth (BHI; Difco Laboratories, Detroit, MI) overnight at $37^{\circ} \mathrm{C}$ for testing.

Mice. Five-week-old female CF\#1/b mice (Takeda Chemical Industries Ltd, Osaka) weighing 19-23 g were used. They were given $5 \%$ glucose solution as the sole source of drinking water from 4 days before an experiment to the end of observation by the method of Keane and Freedman (1967). The mice drank $c .15-20 \mathrm{ml}$ per day. In part of the experiment, mice were given tap water and drank $c .8-10 \mathrm{ml}$ per day. All mice were fed laboratory chow pellets (CLEA Japan Inc., Tokyo) ad libitum.

Determination of urinary virulence. Mice were anaesthetised with $50 \mathrm{mg}$ of sodium pentobarbital (Nembutal; Abott Laboratories, North Chicago, IL) per kg body weight, given intraperitoneally, were forced to void urine by gentle compression of the bladder through the external abdominal wall and $0.05 \mathrm{ml}$ of bacterial suspension was inoculated into the bladder via the urethra. Five mice were used for each inoculum-dose experiment. The bacterial suspensions were prepared from an overnight BHI culture of test strains by tenfold serial dilution with physiological saline solution. The existence of infection was determined by bacteriological examination of the bladder and kidney at 7-9 days after the inoculation. The bladder and kidney were removed aseptically and the bladder was rinsed with $c .30 \mathrm{ml}$ of saline. The inner surface of the bladder and the cut surface of the kidney were imprinted onto MacConkey Agar (MCA; Eiken, Tokyo) and the plates were incubated overnight at $37^{\circ} \mathrm{C}$. The dose required to produce infection in $50 \%$ of mice (ID50) was calculated by the method of Behrens and Kärber (1935).

Viable counts of bacteria in the bladder. Five mice were each inoculated with about $10^{7} \mathrm{cfu}$ of bacteria. The bladder was removed $3 \mathrm{~h}$ after the inoculation and rinsed three times with $c .30 \mathrm{ml}$ of saline. The washed bladder was homogenised in $2 \mathrm{ml}$ of saline and serial tenfold dilutions of the homogenate were cultured quantitatively by the pour-plate method in MCA. The number of bacteria was expressed as the number of cfu per entire organ.

In-vitro adherence test. Overnight BHI cultures of bacteria were washed twice in phosphate-buffered saline, $p \mathrm{H} \mathrm{7.0} \mathrm{(PBS)} \mathrm{for} 20 \mathrm{~min}$ at $1000 \mathrm{~g}$ and resuspended in PBS to give approximately $10^{y} \mathrm{cfu} / \mathrm{ml}$. The bladder was removed aseptically from a mouse and the inner surface was scraped with a microspatula. The bladder epithelial cells thus removed were washed three times in PBS for $10 \mathrm{~min}$ at $50 \mathrm{~g}$ and resuspended in PBS to a concentration of $10^{5} \mathrm{cells} / \mathrm{ml}$. A mixture of $0.2 \mathrm{ml}$ of the bacterial suspension, $0.2 \mathrm{ml}$ of the epithelial-cell suspension and $0.1 \mathrm{ml}$ 
of PBS or $12.5 \%(\mathrm{w} / \mathrm{v})$ D-mannose was incubated at $37 \mathrm{C}$ for $1 \mathrm{~h}$. Unattached bacteria were removed by centrifugation in PBS for $10 \mathrm{~min}$ at $50 \mathrm{~g}$. The final pellet was resuspended in a drop of PBS, dropped onto a glass microscope slide, air dried, fixed with methanol and stained with methylene blue. The number of adherent bacteria on 20 epithelial cells was counted by light microscopy.

Agglutination test. Guinea-pig, chicken, horse and bovine blood samples were purchased from Nippon Bio-Supply Center, Tokyo. Human and mouse blood were freshly collected. The erythrocytes were washed three times with PBS and suspended to a concentration of $2 \%$ $(\mathrm{v} / \mathrm{v})$. A Candida albicans cell suspension was prepared by the method of Ofek and Beachey (1978). The E. coli strains were cultured overnight either in BHI or on TSA at $37^{\circ} \mathrm{C}$ and were suspended in PBS to a concentration of about $10^{9} \mathrm{cfu} / \mathrm{ml}$. Serial twofold dilutions of the bacterial suspensions in $25 \mu \mathrm{l}$ of PBS were made in a microtitration plate (Dynatech Laboratories, Alexandria, VA). To each well, $25 \mu \mathrm{l}$ of the erythrocyte or $C$. albicans cell suspension were added. To test for mannose sensitivity, serial twofold dilutions of the bacterial suspension were prepared in PBS containing 1.5\% (w/v) D-mannose. Agglutination was read after $1 \mathrm{~h}$ at $4 . \mathrm{C}$ in the case of erythrocytes and at room temperature in the case of $C$. albicans cells. The titre was expressed as the highest dilution showing the agglutination.

Electronmicroscopy. A drop of overnight BHI culture of bacteria was placed on a Formvar-coated copper grid and allowed to stand for $2 \mathrm{~min}$. The excess suspension was drained off and adherent bacteria were negatively stained for $30 \mathrm{~s}$ with freshly prepared $2 \%(\mathrm{w} / \mathrm{v})$ ammonium molybdate. Grids were examined in an transmission electron microscope (TEM, Jem-100B; SEOL Ltd, Tokyo) at $80 \mathrm{KV}$.

O serotype was determined by the conventional tube-dilution technique.

Intraperitoneal virulence. Groups of mice were given intraperitoneal injection of about $10^{7}$ cfu of $E$. coli and mortality was determined 5 days later.

Growth in urine. Urine was collected from mice by gentle compression of the bladder through the external abdominal wall and pooled urine samples were filtered through a membrane filter of pore size $0.45 \mu \mathrm{m}$ (Millipore Corporation, Bedford, MA). The sterile urine was inoculated with about $10^{3} \mathrm{cfu} / \mathrm{ml}$. After incubation overnight at $37^{\circ} \mathrm{C}$, growth was determined in TSA by the pour-plate method.

Fermentation of dulcitol was detected by Minitek system (BBL Microbiology Systems, Cockeysville, MD).

Production of haemolysin was tested in liquid and solid media containing sheep- or horse-erythrocytes, by the method of Cooke (1968).

Susceptibility to bactericidal activity of serum. Overnight BHI cultures were diluted 1000 times in Hanks's balanced salts solution (Microbiological Associates, Walkersville, MD) and $10 \mu \mathrm{l}$ of bacterial suspension were added to $100 \mu \mathrm{l}$ of serum freshly obtained from mouse, rabbit or human blood. After incubation for $1 \mathrm{~h}$ the remaining cfu were counted by the pour-plate method in TSA. The results were rated according to the method of Olling (1977); R indicates that less than $50 \%$ of the bacteria were killed, I indicates that $50-99 \%$ were killed and S indicates that more than $99 \%$ were killed.

Susceptibility to antibiotics. Minimal inhibitory concentrations (MICs) of ampicillin (Solucillin, Takeda Chemical Industries, Osaka), streptomycin (Streptomycin Sulfate, Takeda Chemical Industries, Osaka), chloramphenicol (Chloromycetin Powder, Sankyo Seiyaku Co., Tokyo) and tetracycline (Achromycin, Japan Lederle Co., Tokyo) were determined by the agar-dilution method (Tsuchiya et al., 1981). The strains of E. coli not inhibited by these antibiotics at a concentration of $25 \mu \mathrm{g} / \mathrm{ml}$ were regarded as resistant.

Statistical methods. Comparisons of the mean number of bacteria recovered from the bladder wall was by Student's $t$ test. Comparisons of the adhesive capacity to bladder epithelial cells was by the Kruskal-Wall test. Inhibitory effect of D-mannose on the adherence was statistically analysed by the $\chi^{2}$ test.

\section{RESULTS}

\section{Urinary virulence}

The virulence of the $E$. coli in ascending UTI in mice drinking $5 \%$ glucose solution 


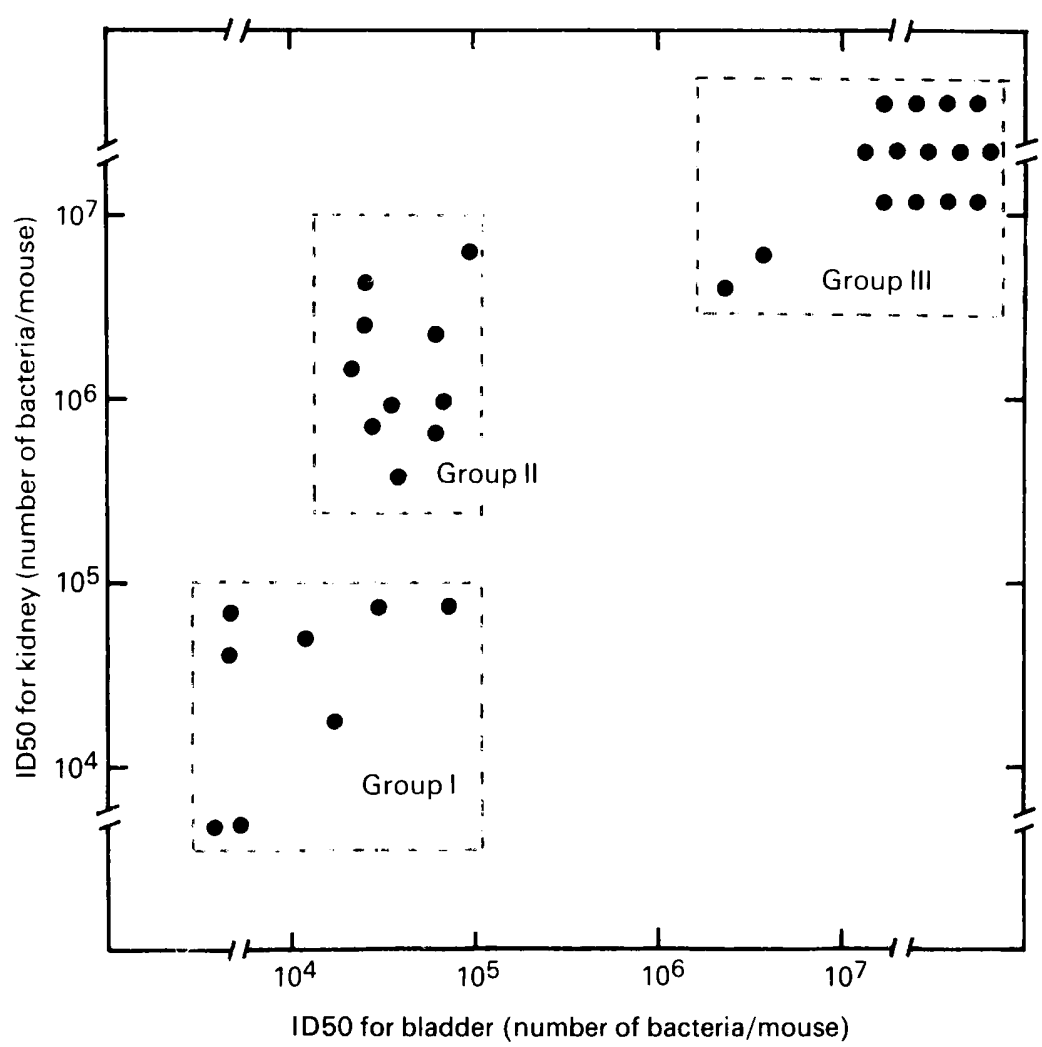

FlG. 1.-Virulence of $E$. coli strains in ascending urinary-tract infections in mice drinking $5 \%$ glucose solution.

was tested (fig. 1). All mice survived for 7-9 days after the bacterial inoculation. The 33 strains were divided into three groups on the basis of the infectivity for the bladder and kidney. Eight strains showed an ID50 of less than $10^{5} \mathrm{cfu}$ in the bladder and kidney (group I); 10 strains showed an ID50 of less than $10^{5} \mathrm{cfu}$ in the bladder and more than $10^{5} \mathrm{cfu}$ in the kidney (group II). The remaining 15 strains failed to produce infection in either bladder or kidney (group III).

In mice drinking tap water, none of the strains produced infection even when $10^{7}$ cfu of bacteria were inoculated into the bladder.

\section{Number of bacteria recovered from the bladder wall}

About $10^{7} \mathrm{cfu}$ of $E$. coli were inoculated into the bladder and the number of bacteria on the bladder wall was counted $3 \mathrm{~h}$ after the inoculation (fig. 2). In the eight strains from group I, the number of bacteria recovered ranged from $3 \times 10^{3}$ to $4 \times 10^{5}$ cfu per bladder. In the 10 strains from group II the number of bacteria recovered ranged from $1 \times 10^{3}$ to $5 \times 10^{5} \mathrm{cfu}$ per bladder. No difference was observed between the geometric mean number of bacteria from group I and that from group II $(p>0 \cdot 8)$. In the 15 strains from group III, bacterial counts ranged from $2 \times 10^{2}$ to $6 \times 10^{4} \mathrm{cfu}$ and the geometric mean was significantly lower than those from groups I and II $(p<0.005)$. 


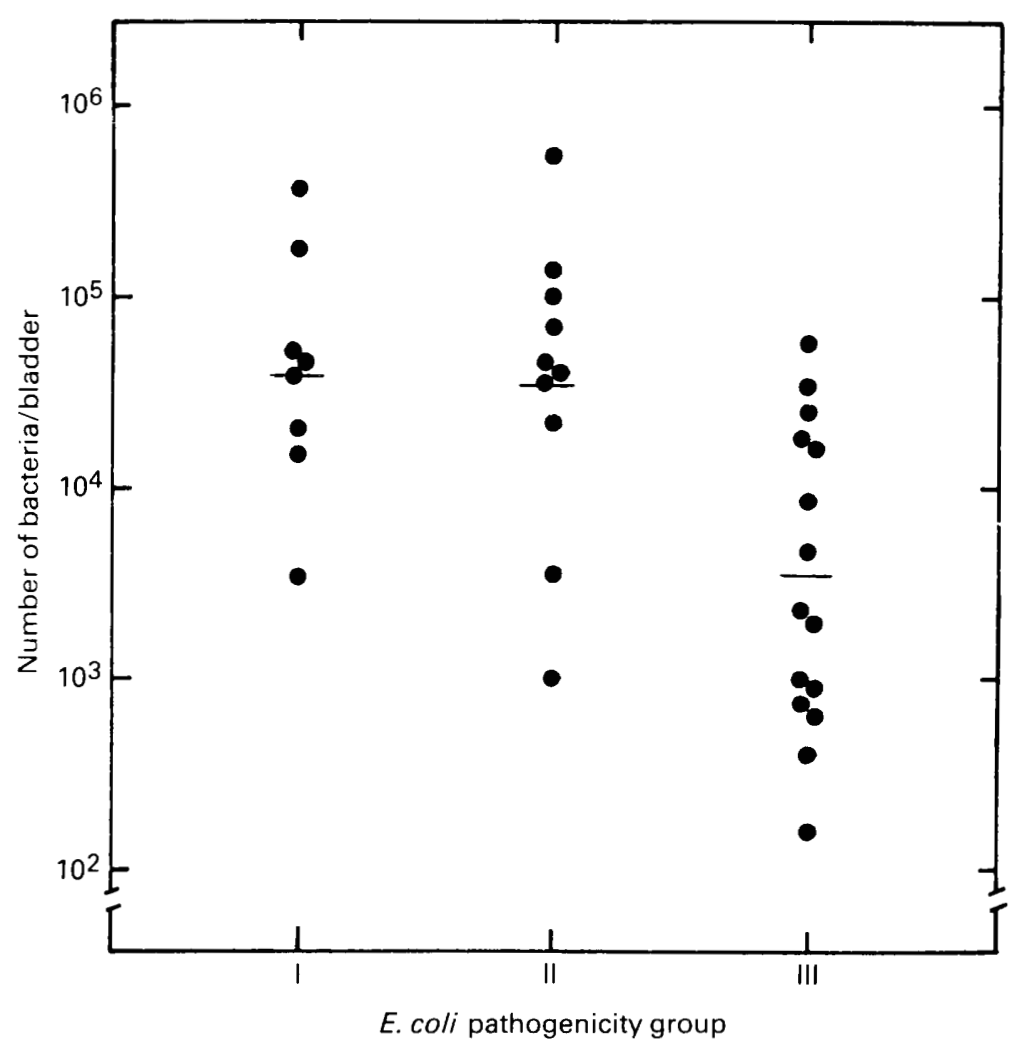

Fig. 2.-The number of bacteria recovered from bladcer wall of mice $3 \mathrm{~h}$ after intra-bladder inoculation of E. coli. Group I comprises strains highly pathogenic for bladder and kidney, group II only for bladder, and group III for neither (see fig. 1). Each point represents the geometric mean count from five mice. The horizontal bar indicates the geometric mean count for virulence group.

\section{Adherence to bladder epithelial cells}

The adhesive capacity of the $E$. coli strains to bladder epithelial cells was compared by the frequency of distribution of bacteria on epithelial cells and by the mean number of bacteria adhering to 20 epithelial cells. Adhering bacteria were clearly seen on the cell surface and were easy to count. Adherence could also be demonstrated by scanning electronmicroscopy (fig. 3). All 18 strains from groups I and II adhered to more than $80 \%$ of epithelial cells and showed a mean number of adhering bacteria ranging from 2.4 to 57.2 bacteria per cell (table I). In group III, only two strains possessed high adhesive capacity with a mean number of adhering bacteria of 11.3 and 20.9 bacteria per cell; the remaining 13 strains hardly adhered to the epithelial cells at all. No difference in adhesive capacity was observed between groups I and II ( $p>0.8)$ but the adhesive capacities from groups I and II were significantly higher than those from group III $(\mathrm{p}<0.01)$. The adherence of 17 of 18 strains from groups I and II was strongly inhibited by D-mannose $(\mathrm{p}<0.005)$ while that of one strain was only weakly inhibited $(p<0.05)$. The adherence of the two strains from groups III with high adhesive capacity was unaffected by D-mannose $(p>0 \cdot 2)$. 


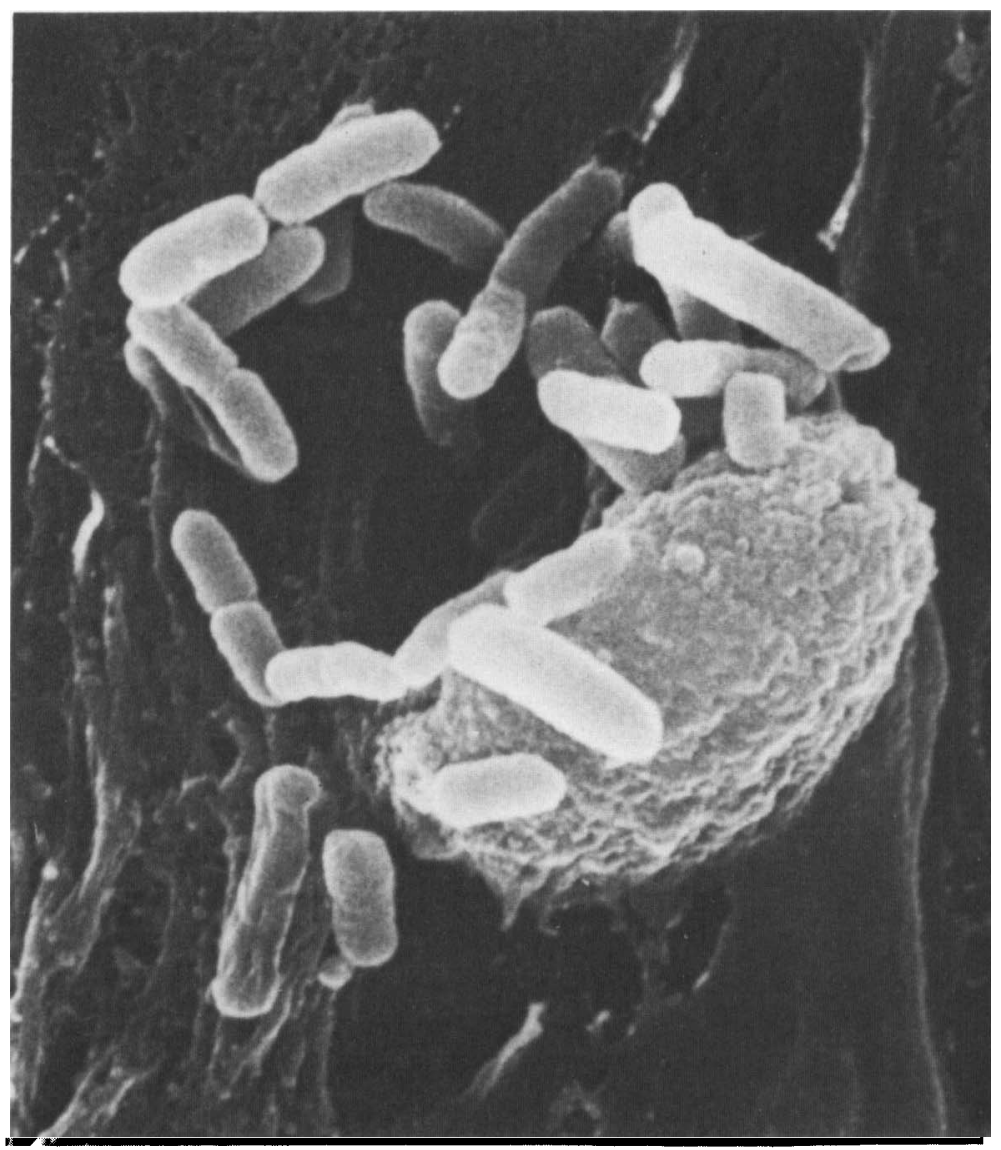

FIG. 3.-Scanning electronmicrograph of $E$. coli adhering to mouse bladder epithelial cells $(\times 16000)$.

\section{Haemagglutination and agglutination of C. albicans}

The agglutination patterns of the $E$. coli strains grown in BHI and the effect of D-mannose on agglutination were tested with guinea-pig, chicken, horse, human, and bovine erythrocytes and with $C$. albicans cells (table II). Eight strains from group I and six of the 10 strains from group II strongly agglutinated guinea-pig erythrocytes and $C$. albicans cells and the agglutination was almost completely inhibited by D-mannose. The majority of these strains also agglutinated chicken and horse erythrocytes in a mannose-sensitive manner. The remaining four strains from group II did not agglutinate any species of erythrocyte tested or $C$. albicans cells except two strains which weakly agglutinated the latter. Of 15 strains from group III, four showed mannose-resistant haemagglutination with various erythrocytes, four showed weak mannose-sensitive agglutination, while the haemagglutination patterns of two strains were of a mixed type. The remaining six strains did not agglutinate $C$. albicans or any species of erythrocytes tested.

The agglutination titres of strains with mannose-sensitive agglutination in the 


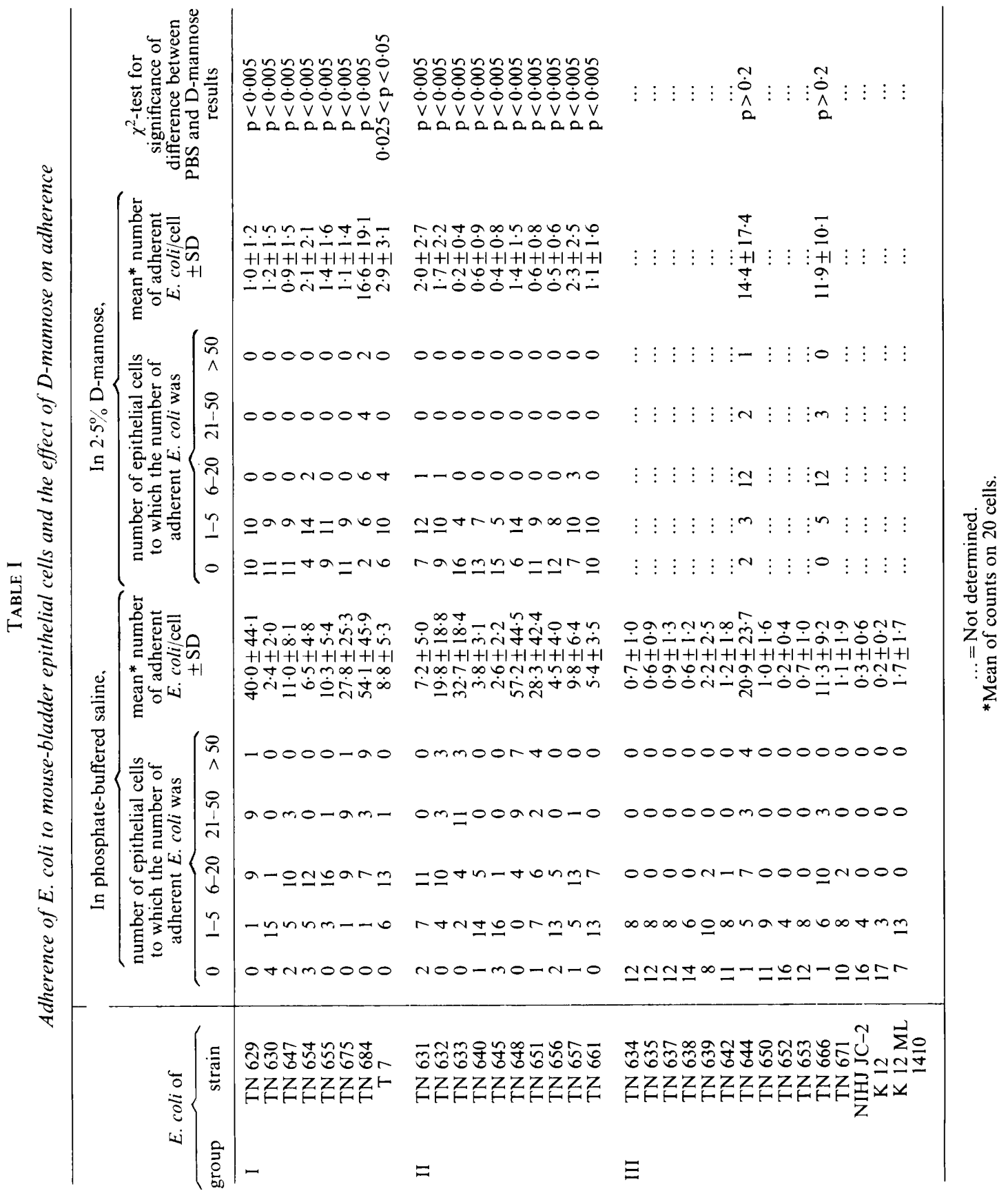


TABLE II

Agglutination patterns of E. coli strains with erythrocytes and yeast cells, bacterial fimbriation and O serotype

\begin{tabular}{|c|c|c|c|c|c|c|c|c|c|c|c|c|}
\hline \multirow{2}{*}{\multicolumn{2}{|c|}{ E. coli of }} & \multicolumn{9}{|c|}{$\begin{array}{l}\text { Agglutination pattern of } \\
\text { indicated erythrocytes in }\end{array}$} & \multirow[b]{3}{*}{ Fimbriation } & \multirow[b]{3}{*}{ O Serotype } \\
\hline & & \multicolumn{7}{|c|}{ broth culture } & \multicolumn{2}{|c|}{ agar culture } & & \\
\hline group & strain & Gp & $\mathrm{Ch}$ & Ho & $\mathrm{Hu}$ & Bo & Mo & $\mathrm{Ca}$ & $\mathrm{Gp}$ & $\mathrm{Ca}$ & & \\
\hline \multirow[t]{8}{*}{ I } & TN 629 & $\mathrm{~s}$ & $\mathrm{~s}$ & $\mathrm{~s}$ & - & - & - & $\mathrm{s}$ & s & - & + & $0-8$ \\
\hline & TN 630 & $\mathrm{~S}$ & $\mathrm{~s}$ & $\mathrm{~S}$ & $\mathrm{~S}$ & - & - & $\mathrm{S}$ & s & $\mathrm{s}$ & + & $0-156$ \\
\hline & TN 647 & $\mathrm{~S}$ & $\mathrm{~s}$ & - & - & - & - & $\mathrm{s}$ & $\mathrm{s}$ & - & + & $0-18$ \\
\hline & TN 654 & $\mathbf{s}$ & $\mathrm{s}$ & - & $\mathrm{R}$ & $\mathrm{r}$ & - & $\mathrm{s}$ & - & - & + & $0-25$ \\
\hline & TN 655 & $\mathrm{~S}$ & s & - & - & - & - & $\mathrm{S}$ & - & - & + & $0-6$ \\
\hline & TN 675 & $\mathrm{~S}$ & $\mathrm{~s}$ & - & - & - & - & $\mathrm{S}$ & $\mathrm{s}$ & $\mathrm{s}$ & + & NG \\
\hline & TN 684 & $\mathrm{~S}$ & $\mathrm{~s}$ & $\mathrm{~s}$ & - & - & - & $\mathrm{S}$ & $\mathrm{s}$ & s & + & $\mathrm{R}$ \\
\hline & T 7 & $\mathrm{~S}$ & s & - & - & - & - & $\mathrm{S}$ & - & - & + & $0-30,-48$ \\
\hline \multirow[t]{10}{*}{ II } & TN 631 & $\mathrm{~S}$ & s & - & - & - & - & $\mathrm{s}$ & - & - & + & $0-30,-48$ \\
\hline & TN 632 & $\mathrm{~S}$ & - & - & - & - & - & $\mathrm{s}$ & $\mathrm{s}$ & - & + & \\
\hline & TN 633 & $\mathrm{~S}$ & $\mathrm{~S}$ & s & - & - & $\mathrm{s}$ & $\mathrm{S}$ & $\mathrm{s}$ & - & + & $0-75$ \\
\hline & TN 640 & - & - & - & - & - & - & $\mathrm{s}$ & - & - & + & $0-18$ \\
\hline & TN 645 & - & - & - & - & - & - & $\mathrm{s}$ & - & $\mathrm{s}$ & + & $0-114$ \\
\hline & TN 648 & $\mathrm{~S}$ & $\mathrm{~s}$ & $\mathrm{~s}$ & - & - & $\mathrm{S}$ & $\mathrm{S}$ & $\mathrm{s}$ & - & + & $0-48$ \\
\hline & TN 651 & - & - & - & - & - & - & - & - & - & + & $0-75$ \\
\hline & TN 656 & - & - & - & - & - & - & - & - & - & + & $0-23$ \\
\hline & TN 657 & $\mathrm{~S}$ & $\mathrm{~s}$ & $\mathrm{~S}$ & $r$ & - & - & $\mathrm{S}$ & $\mathrm{s}$ & $\mathrm{s}$ & + & $\mathrm{R}$ \\
\hline & TN 661 & $\mathrm{~S}$ & $\mathrm{~s}$ & - & - & -- & - & $\mathrm{S}$ & - & $\mathrm{s}$ & + & NG \\
\hline \multirow[t]{15}{*}{ III } & TN 634 & - & - & - & - & - & - & - & - & - & + & $0-6$ \\
\hline & TN 635 & - & - & - & - & - & - & - & - & - & + or - & NG \\
\hline & TN 637 & $\mathrm{~s}$ & - & - & - & - & - & - & - & - & - & NG \\
\hline & TN 638 & - & - & - & - & - & - & - & - & - & - & $0-11$ \\
\hline & TN 639 & s & - & - & - & - & - & $\mathrm{s}$ & - & - & + & $\mathrm{NG}$ \\
\hline & TN 642 & $\mathrm{r}$ & $\mathrm{r}$ & $\mathrm{r}$ & $r$ & $\mathrm{r}$ & - & - & $r$ & - & + & NG \\
\hline & TN 644 & - & - & - & - & s & - & - & - & - & + & $0-91$ \\
\hline & TN 650 & $\mathrm{~s}$ & - & - & - & - & - & $\mathrm{s}$ & - & - & + & $0-40$ \\
\hline & TN 652 & - & - & - & - & - & - & - & - & - & - & $0-75$ \\
\hline & TN 653 & $\mathrm{r}$ & $\mathrm{r}$ & $r$ & - & - & $r$ & - & $r$ & - & - or + & $0-91$ \\
\hline & TN 666 & $\mathrm{~s}$ & - & $\mathrm{r}$ & $\mathrm{R}$ & $r$ & $\mathrm{r}$ & $\mathrm{s}$ & $\mathrm{R}$ & - & + & $0-18$ \\
\hline & TN 671 & $\mathrm{R}$ & $r$ & $\mathrm{r}$ & $\mathrm{R}$ & $\mathrm{r}$ & $\mathrm{r}$ & - & $\mathrm{R}$ & - & - or + & $\mathrm{R}$ \\
\hline & NIHJ JC-2 & - & - & - & - & - & - & - & - & - & - & $\mathrm{R}$ \\
\hline & K 12 & $\mathrm{r}$ & $r$ & $\mathrm{r}$ & $r$ & $\mathrm{r}$ & $r$ & - & - & - & - & $\mathrm{R}$ \\
\hline & $\begin{array}{l}\mathrm{K} 12 \mathrm{ML} \\
1410\end{array}$ & $\mathrm{r}$ & $\mathrm{s}$ & $\mathrm{r}$ & $\mathrm{r}$ & $\mathrm{s}$ & $\mathrm{s}$ & $\mathrm{s}$ & $\mathrm{r}$ & - & + & $\mathrm{R}$ \\
\hline
\end{tabular}

$\mathrm{Gp}=$ guinea-pig; $\mathrm{Ch}=$ chicken; $\mathrm{Ho}=$ horse; $\mathrm{Hu}=$ human; $\mathrm{Bo}=$ bovine; $\mathrm{Mo}=$ mouse; $\mathrm{Ca}=$ Candida albicans.

$\mathrm{S}=$ mannose-sensitive agglutination with high $(\geqslant 16)$ titre; $\mathrm{s}=$ mannose-sensitive agglutination with low $(<16)$ titre; $R=$ mannose-resistant agglutination with high $(\geqslant 16)$ titre; $r=$ mannose-resistant agglutination with low $(<16)$ titre; $-=$ no agglutination.

$+=$ fimbriate $-=$ non-fimbriate.

$\mathrm{R}=$ autoagglutinated in saline; $\mathrm{NG}$ : not groupable.

absence of D-mannose were always higher when the strain was grown in BHI than when it was grown on TSA but the titres of the strains with the mannose-resistant agglutination were almost invariable.

\section{Electronmicroscopy}

Electronmicrographs of $E$. coli strain TN 629 from group I and $E$. coli strain TN 652 from group III grown in $\mathrm{BHI}$ overnight at $37^{\circ} \mathrm{C}$ are shown in figs 4 and 5 , 


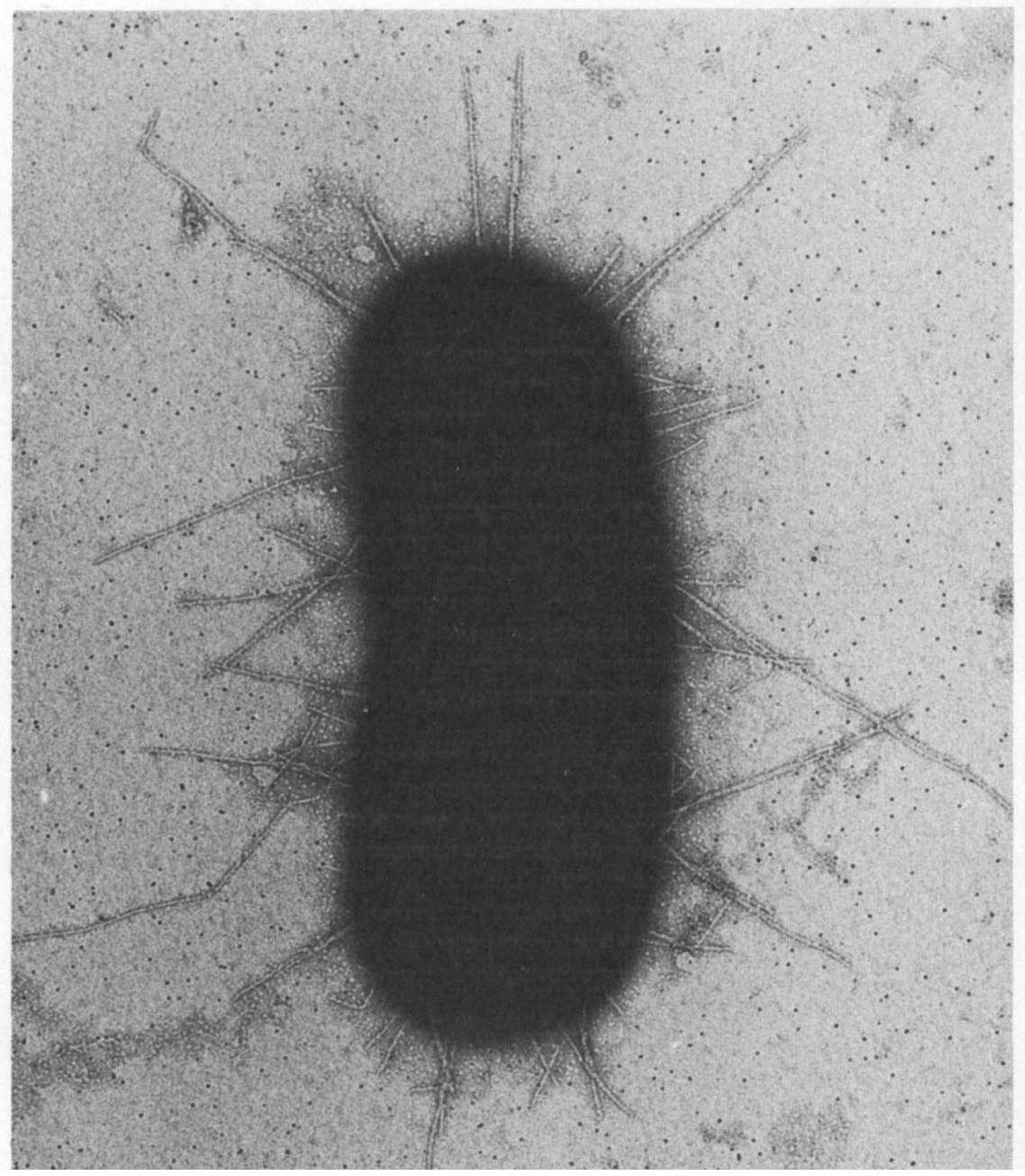

FIG. 4.-Electronmicrograph of E. coli strain TN629 with fimbriae $(\times 40000)$.

respectively. All 18 strains of groups I and II, and eight of 15 strains from group III possessed similar fimbriae as shown in fig. 4 . In the remaining seven strains, including strain TN 652, these appendages were not observed (table III).

\section{Other biological properties}

No significant correlation was found between urinary virulence and other biological properties, such as $\mathrm{O}$ serotype (table II), lethality on intraperitoneal injection in mice, ability to grow in mouse urine, ability to ferment dulcitol, production of haemolysin, susceptibility to serum bactericidal activity, and susceptibility to antibiotics (table III). 


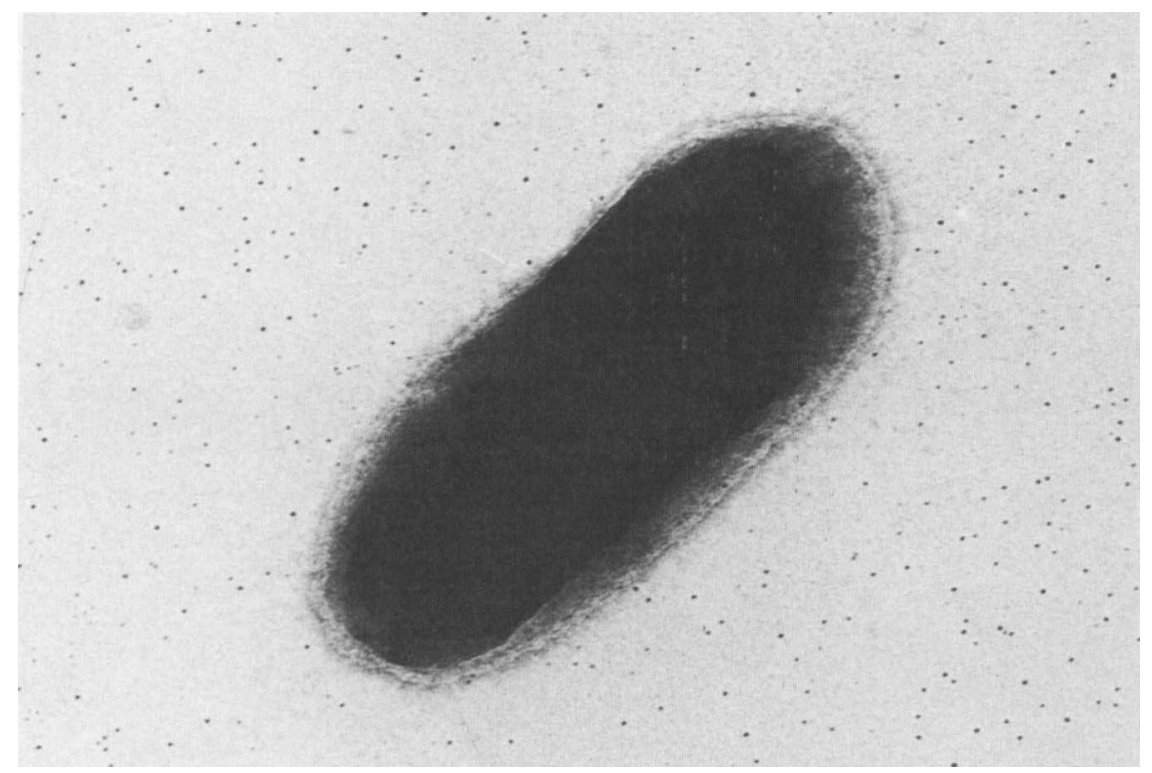

FIG. 5.-Electronmicrograph of E. coli strain TN652 without fimbriae $(\times 60000)$.

TABLE III

Some biological properties of E. coli strains of groups I, II and III (as defined in the text)

\begin{tabular}{|c|c|c|c|}
\hline \multirow{2}{*}{ Test } & \multicolumn{3}{|c|}{$\begin{array}{l}\text { Number of strains giving } \\
\text { positive reaction among }\end{array}$} \\
\hline & $\begin{array}{l}8 \text { strains of } \\
\text { group I }\end{array}$ & $\begin{array}{l}10 \text { strains of } \\
\text { group II }\end{array}$ & $\begin{array}{l}15 \text { strains of } \\
\text { group III }\end{array}$ \\
\hline $\begin{array}{l}\text { Mouse lethality by intraperitoneal injection of } \\
\text { tap water } \\
5 \% \text { glucose }\end{array}$ & $\begin{array}{l}7 \\
7\end{array}$ & $\begin{array}{l}4 \\
3\end{array}$ & $\begin{array}{l}6 \\
4\end{array}$ \\
\hline $\begin{array}{l}\text { Growth in mouse urine in } \\
\text { tan water }\end{array}$ & & & \\
\hline $\begin{array}{l}\text { tap water } \\
5^{\circ} \text { glucose }\end{array}$ & 0 & 0 & 0 \\
\hline $5 \%$ glucose & 8 & 10 & 15 \\
\hline Dulcitol fermentation & 7 & 8 & 10 \\
\hline $\begin{array}{l}\text { Haemolysin production in } \\
\text { broth medium }\end{array}$ & & & \\
\hline $\begin{array}{l}\text { broth medium } \\
\text { agar medium }\end{array}$ & 3 & 1 & $\begin{array}{l}4 \\
4\end{array}$ \\
\hline $\begin{array}{l}\text { Resistance to bactericidal activity } \\
\text { of serum from }\end{array}$ & & & \\
\hline human serum & 3 & 3 & 3 \\
\hline rabbit serum & 7 & 7 & 6 \\
\hline mouse serum & 8 & 10 & 15 \\
\hline Resistance to antibiotics* & 3 & 8 & 10 \\
\hline
\end{tabular}

*Ampicillin, streptomycin, chloramphenicol and tetracycline.

\section{Discussion}

Strain-specific differences in the ability of $E$. coli to induce UTI in experimental animals have been reported by several authors. In most of these studies, however, inoculation by the haematogenous route was used (Brumfitt and Heptinstall, 1960; 
Kimball, Turck and Petersdorf, 1964; Prat et al., 1965; Fried et al., 1971; van den Bosch, de Graaff and MacLaren, 1979). The ascending route of infection was used in our study because it most closely parallels the usual clinical situation. The E. coli strains tested were classified into three groups according to their ability to induce UTI in mice drinking $5 \%$ glucose solution. Of 33 strains, eight strains (group I) induced UTI involving the bladder and the kidney and 10 strains (group II) induced infections localised to the bladder, while the remaining 15 strains (group III) did not cause infection. Nicholson and Glynn (1975) investigated the renal pathogenicity of seven strains of $E$. coli using an ascending model in mice with foreign bodies in the bladder, and found differences among the strains in the dose infecting $50 \%$ of kidneys. Guze et al. (1973) tested the virulence of 22 strains of $E$. coli using the same model as in the present study and showed that there were marked differences among the strains in the ability to produce renal infection and death. In our study, none of the strains, at the inoculum sizes tested, caused death. This discrepancy may be due to strain differences of the mice or of the $E$. coli strains used.

Various biological properties of $E$. coli are reported as factors influencing virulence for the urinary tract (Montgomerie, 1978). Of several properties examined in the present study, the adhesive capacity of the strains to bladder epithelial cells related positively with their ability to induce UTI. The strains of groups I and II showed significantly higher counts than the group-III strains in bacterial recovery from the bladder wall $3 \mathrm{~h}$ after inoculation. Furthermore, strains of groups I and II adhered well in vitro to bladder epithelial cells in a mannose-sensitive manner, but most of the group-III strains barely adhered to the epithelial cells. These observations suggest that adherence of $E$. coli to bladder epithelial cells plays an important role in the development of experimental UTI in mice. In recent years, evidence has accumulated, for various bacterial infections, that adherence of bacteria to mucosal surfaces of a susceptible host is an important step in colonisation and infection (Ofek and Beachey, 1980). Although the role of bacterial adherence in the pathogenesis of human UTI is not thoroughly clear, several authors have suggested a more or less positive correlation between the clinical pathogenicity of $E$. coli in UTI and its adhesive capacity to uroepithelial cells (Svanborg Ede̊n et al., 1976; Schaeffer et al., 1979; Källenius et al., 1980; van den Bosch et al., 1980). The results presented here support these epidemiological findings.

The ability of $E$. coli to adhere to epithelial cells is often associated with surface structures called fimbriae which can be classified into various types by dimension, composition, stability, antigenicity, adhesive specificity, and agglutination patterns with erythrocytes and yeast cells (Duguid and Old, 1980). All strains of groups I and II possessed fimbriae and their adherence to bladder epithelial cells was inhibited by D-mannose. Furthermore, most of these strains agglutinated erythrocytes of guinea-pig, chicken, and horse, and $C$. albicans cells in a mannose-sensitive manner; the agglutination titres were always higher when the $E$. coli had been grown in BHI than on TSA. These results indicate that most strains of groups I and II possess fimbriae closely related to the so-called type-1 fimbriae. On the other hand, the adherence and haemagglutination of two group-III strains with high adhesive capacity were not affected by D-mannose. From these findings, it appears that the adherence of most strains of groups I and II to bladder epithelial cells is mediated by type- 1 or closely related fimbriae, which play an important role in the development of UTI in 
mice. Aronson et al. (1979) showed that the incidence of UTI with E. coli in diuresed mice was markedly reduced by inoculation into the bladder of bacteria suspended in D-mannose solution, probably because of inhibition of bacterial adherence to the bladder mucosal surfaces by D-mannose. Salit and Gotschlich (1977a and $b$ ) demonstrated that purified type-1 fimbriae from E. coli attached to monkey-kidney cells in tissue culture and agglutinated guinea-pig erythrocytes in a mannose-sensitive manner. Fader, Avots-Avotins and Davis (1979) and Fader and Davis (1980) found that the fimbriae of Klebsiella pneumoniae, similar to type-1 fimbriae of E. coli, play an integral role in the ability to cause cystitis in rat by mediating the attachment of the bacteria to the uroepithelial surface. In contrast, the adherence of $E$. coli isolated from human UTI to human uroepithelial cells has not always been found to be inhibited by D-mannose (Svanborg Ede̊n, 1978, van den Bosch et al., 1980). Ørskov, Ørskov and Birch-Andersen (1980) suggested that a new type of fimbria, referred to as F7, mediated the adherence of $E$. coli to human uroepithelial cells and they state that $E$. coli with type-1 fimbriae specifically adhered to urinary mucus rather than to the actual cell surface; the adhesive property of type- 1 fimbriae does not seem to be essential for the development of human UTI. It is known that the adherence of some pathogens varies from host to host and from tissue to tissue (Ofek and Beachey, 1980). Korhonen, Leffler and Svanborg Ede̊n (1981) have found that four pilated strains of E. coli and Salmonella typhimurium attached to human buccal cells, but two strains with a mannose-resistant agglutination adhered only to human urinary tract cells and another two strains with mannose-sensitive agglutination adhered only to rat urinary-tract cells. The discrepancy between animal models and human infection may be related to differences between the epithelial cells used in the studies.

We thank Dr K. Tamura of the National Institute of Health, Japan, for O-serotyping of the strains of E. coli.

\section{REFERENCES}

Aronson, M., Medalia, O., Schori, L., Mirelman, D., Sharon, N. and Ofek, I. 1979. Prevention of colonization of the urinary tract of mice with Escherichia coli by blocking of bacterial adherence with methyl $\alpha$-D-mannopyranoside. Journal of Infectious Diseases, 139, 329-332.

BEHRENS, B. AND KÄRBER, G. 1935. Wie sind Reihenversuche für biologische Auswertungen am zweckmässigsten anzuorden? Archives of Experimental Pathology and Pharmacology, 177, 379-388.

BJÖRKSTEN, B. AND KAIJSER, B. 1978. Interaction of human serum and neutrophils with Escherichia coli strains; differences between strains isolated from urine of patients with pyelonephritis or asymptomatic bacteriuria. Infection and Immunity, 22, 308-311.

BRumfitT, W. AND HePTinstall, R. H. 1960. Experimental pyelonephritis; the relationship of bacterial virulence to the establishment of the renal lesion. British Journal of Experimental Pathology, 41, 552-558.

COOKE, E. M. 1968. Properties of strains of Escherichia coli isolated from the faeces of patients with ulcerative colitis, patients with acute diarrhoea and normal persons. Journal of Pathology and Bacteriology, 95, 101-113.

COOKE, E. M. AND EwINs, S. P. 1975. Properties of strains of Escherichia coli isolated from a variety of sources. Journal of Medical Microbiology, 8, 107-111.

Cotran, R. S. 1969. Experimental pyelonephritis. In The kidney, vol. 2, edited by C. Rouiller and A. F. Muller, Academic Press, New York, pp. 269-361.

Duguid, J. P. AND OLD, D. C. 1980. Adhesive properties of enterobacteriaceae. In Bacterial adherence, edited by E. H. Beachey, Chapman and Hall, London, pp. 185-217. 
Fader, R. C., Avots-Avotins, A. E. And Davis, C. P. 1979. Evidence for pili-mediated adherence of Klebsiella pneumoniae rat bladder epithelial cells in vitro. Infection and Immunity, 25, 729-737.

FadER, R. C. AND DAVIS, C. P. 1980. Effect of piliation on Klebsiella pneumoniae infection in rat bladders. Infection and Immunity, 30, 554-561.

Fried, F. A., Vermeulen, C. W., Ginsburg, M. J. and Cone, C. M. 1971. Etiology of pyelonephritis: further evidence associating the production of experimental pyelonephritis with hemolysis in Escherichia coli. Journal of Urology, 106, 351-354.

GLYNN, A. A., BRUMfITt, W. AND HowARD, C. J. 1971. K antigens of Escherichia coli and renal involvement in urinary tract infections. Lancet, 1, 514-516.

Guze, L.B., Montgomerie, J. Z., Potter, C. S. and Kalmanson, G. M. 1973. Pyelonephritis. XVI. Correlates of parasite virulence in acute ascending Escherichia coli pyelonephritis in mice undergoing diuresis. Yale Journal of Biology and Medicine, 46, 203-211.

KAIJSER, B. 1973. Immunology of Escherichia coli: K antigen and its relation to urinary-tract infection. Journal of Infectious Diseases, 127, 670-677.

Kaijser, B., Hanson, L. A., Jodal, U., Lidin-Janson, G. and Robbins, J. B. 1977. Frequency of $E$. coli $\mathrm{K}$ antigens in urinary tract infections in children. Lancet, 1, 663-664.

Keane, W. F. and FreEDMan, L. R. 1967. Experimental pyelonephritis. XIV. Pyelonephritis in normal mice produced by inoculation of $E$. coli into the bladder lumen during water diuresis. Yale Journal of Biology and Medicine, 40, 231-237.

Kimball, H., Turck, M. and Petersdorf, R. G. 1964. The epidemiology of nonenteric Escherichia coli infections. III. Relationship of $E$. coli antigens to experimental pyelonephritis. Journal of Laboratory and Clinical Medicine, 63, 907-913.

KälleNiUS, G., Möllbi, R. AND WinberG, J. 1980. In vitro adhesion of uropathogenic Escherichia coli to human periurethral cells. Infection and Immunity, 28, 972-980.

Korhonen, T. K., LeFfler, H. ANd SVANBorg EdE̊n, C. 1981. Binding specificity of piliated strains of Escherichia coli and Salmonella typhimurium to epithelial cells, Saccharomyces cerevisiae cells, and erythrocytes. Infection and Immunity, 32, 796-804.

McCabe, W. R., Carling, P. C., Bruins, S. and Greely, A. 1975. The relation of K antigen to virulence of Escherichia coli. Journal of Infectious Diseases, 131, 6-10.

Minshew, B. H., Jorgensen, J., Swanstrum, M., Grootes-Reuvecamp, G. A. and Falkow, S. 1978. Some characteristics of Escherichia coli strains isolated from extraintestinal infections of humans. Journal of Infectious Diseases, 137, 648-654.

MONTGOMERIE, J. Z. 1978. Factors affecting virulence in Escherichia coli urinary tract infections. Journal of Infectious Diseases, 137, 645-647.

Nicholson, A. M. AND GLYNN, A. A. 1975. Investigation of the effect of K antigen in Escherichia coli urinary tract infections by use of a mouse model. British Journal of Experimental Pathology, 56, 549-553.

OFEK, I. AND BEACHEY, E. H. 1978. Mannose binding and epithelial cell adherence of Escherichia coli. Infection and Immunity, 22, 247-254.

OFEK, I. AND BEACHEY, E. H. 1980. General concepts and principles of bacterial adherence in animals and man. In Bacterial adherence, edited by E. H. Beachey, Chapman and Hall, London, pp. 1-29.

OlLING, S. 1977. Sensitivity of gram-negative bacilli to the serum of bactericidal activity: a marker of the host-parasite relationship in acute and persisting infections. Scandinavian Journal of Infectious Diseases, supplement 10, 1-40.

Ørskov, I., ØRSKov, F. AND BIRCh-ANDERSEN, A. 1980. Comparison of Escherichia coli fimbrial antigen F7 with type I fimbriae. Infection and Immunity, 27, 657-666.

Prat, V., Hatala, M., Benesova, D. and Rossmann, P. 1965. Pathogenicity of various strains of Escherichia coli for the intact rabbit kidney and the effect of repeated passage on renal tissue. In Progress in pyelonephritis, edited by E. H. Kass, Davis, Philadelphia, pp. $135-146$.

Salit, I. E. And Gotschlich, E. C. $1977 a$. Hemagglutination by purified type 1 Escherichia coli pili. Journal of Experimental Medicine, 146, 1169-1181.

Salit, I. E. AND Gotschlich, E. C. $1977 b$. Type 1 Escherichia coli pili: characterization of binding to monkey kidney cells. Journal of Experimental Medicine, 146, 1182-1194. 
SChaEfFer, A. J., Amundsen, S. K. AND Schmidt, L. N. 1979. Adherence of Escherichia coli to human urinary tract epithelial cells. Infection and Immunity, 24, 753-759.

SVANBORG EDE̊N, C. 1978. Attachment of Escherichia coli to human urinary tract epithelial cells. Scandinavian Journal of Infectious Diseases, supplement 15, 1-6.

Svanborg EdE̊n, C., Hanson, L. A., Jodel, U., Lindberg, U. and Akerlund, A. S. 1976. Variable adherence to normal human urinary tract epithelial cells of Escherichia coli strains associated with various forms of urinary-tract infection. Lancet, 2, 490-492.

TsuCHIYA, K. and seven others. 1981. Cefmenoxime (SCE-1365), a novel broad-spectrum cephalosporin: in vitro and in vivo antibacterial activities. Antimicrobial Agents and Chemotherapy, 19, 56-65.

Turck, M., Petersdorf, R. G. and Fournier, M. R. 1962. The epidemiology of non-enteric Escherichia coli infections: prevalence of serological groups. Journal of Clinical Investigation, 41, 1760-1765.

van den Bosch, J. F., De Graaff, J. and Maclaren, D. M. 1979. Virulence of Escherichia coli in experimental hematogenous pyelonephritis in mice. Infection and Immunity, 25, 68-74.

van den Bosch, J. F., Verboom-Sohmer, U., Postma, P., de Graff, J. and Maclaren, D. M. 1980. Mannose-sensitive and mannose-resistant adherence to human uroepithelial cells and urinary virulence of Escherichia coli. Infection and Immunity, 29, 226-233.

Vosti, K. L., Goldberg, L. M., Monto, A. S. and Rantz, L. A. 1964. Host-parasite interaction in patients with infections due to Escherichia coli. I. The serogrouping of $E$. coli from intestinal and extraintestinal sources. Journal of Clinical Investigation, 43, 2377-2385. 